\title{
PROBLEM SOLVING: SUATU PENDEKATAN PEMBELAJARAN UNTUK MENINGKATKAN HASIL BELAJAR PESERTA DIDIK
}

\section{PROBLEM SOLVING: A LEARNING APPROACH TO IMPROVE STUDENTS' LEARNING OUTCOMES}

\author{
Andi Dian Angriani'), Fitriani Nur'), Rahmawati Nur ${ }^{3)}$ \\ 1,2) Fakultas Tarbiyah dan Keguruan Universitas Islam Negeri Alauddin Makassar \\ 3)MTs Negeri 1 Makassar \\ dian.angriani@uin-alauddin.ac.id ${ }^{1}$, fitrianinur@uin-alauddin.ac.id ${ }^{2}$, \\ rahmawatinurkadir@yahoo.co.id ${ }^{3}$ )
}

\begin{abstract}
Abstrak
Penelitian ini bertujuan untuk mengetahui peningkatan hasil belajar peserta didik melalui pendekatan problem solving. Jenis penelitian yang digunakan adalah penelitian tindakan kelas yang terdiri dari dua siklus, melalui beberapa tahapan, yaitu perencanaan, pelaksanaan tindakan, observasi, dan refleksi. Subjek penelitian ini adalah siswa kelas VIII, MTs Negeri 1 Makassar yang berjumlah 40 peserta didik. Tindakan yang diberikan adalah dengan menerapkan pendekatan problem solving. Hasil penelitian ini menunjukkan bahwa pendekatan problem solving dapat meningkatkan hasil belajar peserta didik, terlihat pada siklus I skor rata-rata hasil belajar peserta didik yaitu 79,48 dan persentase peserta didik yang memenuhi Kriteria Ketuntasan Minimal (KKM) sebesar 65\%, sementara pada siklus II skor rata-rata hasil belajar peserta didik meningkat menjadi 89,40 serta persentase peserta didik yang memenuhi KKM meningkat menjadi 87,50 \%. Dengan demikian, hasil belajar matematika peserta didik dapat meningkat melalui penerapan pendekatan problem solving.
\end{abstract}

Kata Kunci: problem solving, hasil belajar, matematika

\begin{abstract}
This study aims to determine the improvement in student learning outcomes through a problem solving approach. The type of research used is classroom action research which consists of two cycles, through several stages, namely planning, implementing action, observing, and reflecting. The subjects of this study were 40 students of class VIII9 MTs Negeri 1 Makassar. The action given is to apply a problem solving approach. The results of this study indicate that problem solving approach can improve students' learning achievement, seen in the first cycle the average score of student learning outcomes is 79.48 and the percentage of students who meet the minimum completeness criteria is 65\%, while in the second cycle the average score student learning outcomes increased to 89.40 and the percentage of students who met the minimum completeness criteria increased to $87.50 \%$. Thus, students' mathematics learning achievement can be increased through the implementation of problem solving approach.
\end{abstract}

Keywords: problem solving, learning achievement, mathematics

How to Cite: Angriani, A. D., Nur, F., \& Nur, R. (2020). Problem solving: suatu pendekatan pembelajaran untuk meningkatkan hasil belajar peserta didik. Al asma: Journal of Islamic Education, 2(2), 151-159. 


\section{PENDAHULUAN}

Matematika merupakan salah satu mata pelajaran yang diajarkan di semua jenjang pendidikan yang berperan penting dalam kehidupan sehari-hari, sebab matematika membuat manusia dapat berfikir secara logis dan sistematis. Belajar matematika merupakan suatu aktivitas yang ada kaitannya dalam kehidupan sehari-hari (Nur'aini, Harahap, Badruzzaman, \& Darmawan, 2017; Harahap \& Makmur, 2018). Sementara itu, Kusumaningtyas (2016) menganggap bahwa matematika merupakan ilmu dasar yang terus berkembang dari segi teori maupun penerapannya yang digunakan di segala bidang kehidupan manusia. Oleh karena itu, diperlukan suatu cara dalam melakukan proses belajar mengajar agar dapat terlaksana secara optimal.

Lubis \& Azizan (2018) mengungkapkan bahwa salah satu indikator keberhasilan dalam pembelajaran matematika, yakni penggunaan metode, model, ataupun pendekatan pembelajaran yang diterapkan oleh guru. Namun demikian, Jika penerapan metode, model, ataupun pendekatan tidak sesuai yang diharapkan, dapat menghambat tercapainya tujuan yang diharapkan, salah satunya adalah kemampuan memecahkan masalah. Dalam pembelajaran matematika, pemecahan masalah merupakan kemampuan dasar dalam proses pembelajaran (Hidayat \& Sariningsih, 2018). Dengan pemecahan masalah, seseorang akan dapat berpikir menyelesaikan masalah secara sistematis, kritis, logis (Nengsih, Susiswo, Sa'dijah, 2019). Dengan demikian, melalui proses pemecahan masalah matematika, diharapkan dapat memberikan solusi terhadap suatu masalah yang diberikan, termasuk kemampuan berpikir peserta didik dapat ditingkatkan melalui pemecahan masalah.

Berdasarkan hasil observasi yang dilakukan penulis di MTs Negeri 1 Makassar, ditemukan bahwa peserta didik kesulitan dalam menyelesaikan soal-soal matematika yang disajikan dalam bentuk suatu masalah, peserta didik juga kurang aktif dalam proses pembelajaran, peserta didik kurang aktif bertanya maupun memberikan tanggapan, akibatnya prestasi peserta didik menjadi menurun. Salah satu penyebabnya pada umumnya hanya diberikan penjelasan terkait materi dan meminta peserta didik untuk mengerjakan soal yang sifatnya rutin, dan sebaiknya soal-soal yang diberikan sebaiknya dikemas dalam bentuk soal cerita. Selain itu, perlu diterapkan pendekatan pembelajaran yang sesuai dengan kondisi peserta didik di sekolah. Dalam mengatasi hal tersebut, perlu diterapkan suatu pendekatan pembelajaran yang dapat meningkatkan hasil belajar peserta didik, salah satunya adalah pendekatan pemecahan masalah (problem solving). Menurut Shoimin (2014) problem solving adalah suatu pendekatan pembelajaran yang fokusnya pada pengajaran dan keterampilan pemecahan masalah, serta diberikan penguatan keterampilan. Dalam hal ini, pendekatan problem solving sangat cocok diterapkan untuk melatih peserta didik berfikir kreatif dalam menghadapi berbagai masalah, baik masalah pribadi maupun masalah dalam kelompok. Peserta didik dapat belajar sendiri mengidentifikasi penyebab masalah dan mencari solusi untuk memecahkan masalahnya. Menurut Alipandie (1984) problem solving adalah cara mengajar yang dilakukan dengan cara melatih peserta didik menghadapi berbagai masalah untuk diselesaikan sendiri atau secara bersama-sama.

Menurut Hamalik (2003), pendekatan problem solving adalah suatu pendekatan pembelajaran yang melibatkan proses mental dan intelektual dalam menemukan dan menyelesaikan masalah, sehingga dapat dibuat suatu kesimpulan yang tepat dan cermat. 
Pemecahan masalah (problem solving). Menurut Polya, langkah-langkah menyelesaikan suatu masalah, yaitu memahami masalah, merencanakan masalah, menyelesaikan masalah sesuai rencana, dan melakukan pengecekan kembali terhadap semua langkah yang dikerjakan (Hidayat \& Sariningsih, 2018). Tahap dalam pemecahan masalah, saling terkait untuk menghasilkan pemecahan masalah yang termuat dalam masalah yang diberikan. Peserta didik berperan dalam memahami dan menyelesaikan setiap langkah dalam pemecahan masalah untuk menghasilkan solusi terhadap persoalan. Berdasarkan definisi yang dikemukakan di atas, dapat dikatakan bahwa problem solving merupakan suatu pendekatan yang dapat diterapkan untuk mencari informasi, menganalisis situasi, mengidentifikasi masalah, serta mencari solusi atau penyelesaian terhadap suatu masalah, sehingga dapat mengambil suatu keputusan.

Berdasarkan hasil penelitian yang dilakukan oleh Imelda (2018) menunjukkan bahwa penerapan pendekatan problem solving dapat meningkatkan kemampuan pemecahan masalah mahasiswa pada mata kuliah Aljabar dan Trigonometri. Selain itu, penelitian yang dilakukan oleh Maesari, Marta, R \& Yusnira (2020), memaparkan bahwa problem solving dapat meningkatkan kemampuan pemecahan masalah matematika peserta didik pada operasi hitung bilangan cacah. Demikian juga penelitian yang dilakukan oleh Mardianis (2018) menunjukkan bahwa penerapan pendekatan problem solving dapat meningkatkan hasil belajar IPA peserta didik. Oleh karena itu, peneliti tertarik menulis artikel yang bertujuan untuk mengetahui peningkatan hasil belajar peserta didik melalui penerapan pendekatan problem solving.

\section{METODE PENELITIAN}

Jenis penelitian ini adalah penelitian tindakan kelas (PTK). Penelitian ini dilakukan dengan dua siklus, yaitu siklus I dan siklus II, masing-masing terdiri dari tiga kali pertemuan. Subjek penelitian ini adalah kelas VIII.9 MTs Negeri 1 Makassar yang berjumlah 40 peserta didik. Fokus dalam Penelitian Tindakan Kelas ini adalah penerapan pendekatan problem solving, yaitu suatu pendekatan pembelajaran yang membangun kemampuan peserta didik untuk mencari informasi, menganalisis situasi, dan mengidentifikasi masalah. Langkahlangkah penelitian ini, antara lain perencanaan, pelaksanaan, observasi, dan refleksi (Mustami, 2012) yang dapat dilihat pada gambar berikut.

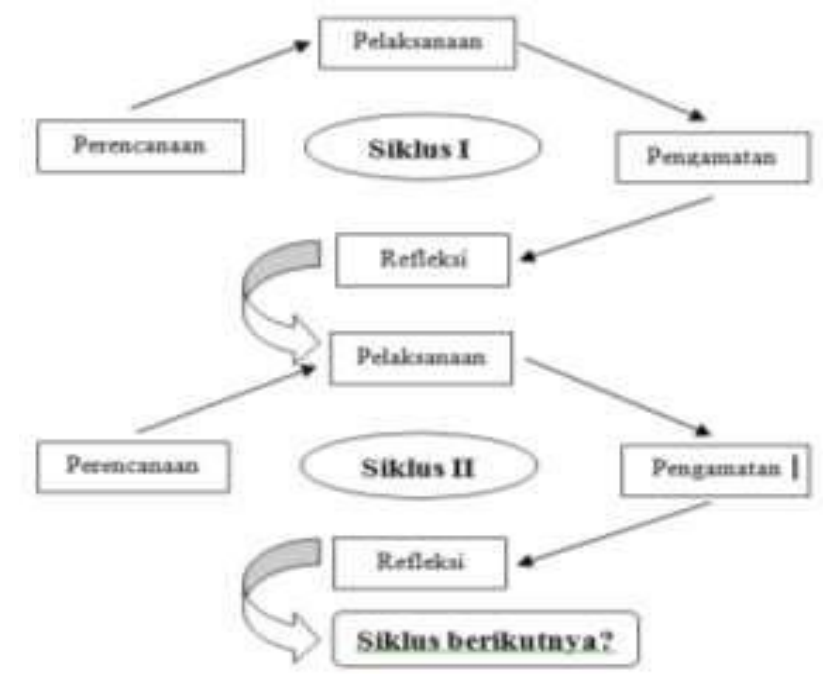

Gambar 1. Langkah-Langkah Penelitian Tindakan Kelas 
Penelitian tindakan kelas ini terdiri dari dua siklus. Pelaksanaan setiap siklus dilakukan berdasarkan perubahan yang ingin dicapai. Pelaksanaan siklus I dan siklus II saling berkaitan. Siklus II merupakan lanjutan dan perbaikan dari pelaksanaan siklus I. Agar peningkatan prestasi peserta didik dalam mengikuti pembelajaran matematika dapat diketahui, maka digunakan teknik analisis, yakni data teknik analisis deskriptif.

Adapun indikator keberhasilan setiap akhir siklus ditetapkan berdasarkan ketentuan sebagai berikut: (a) apabila skor rata-rata hasil belajar peserta didik meningkat melalui penerapan pendekatan problem solving, (b) apabila peserta didik telah mencapai Kriteria Ketuntasan Minimal (KKM) $\geq 75$ dengan ketuntasan klasikal $\geq 80 \%$.

\section{HASIL DAN PEMBAHASAN}

\section{Hasil Pengamatan Siklus I}

Berdasarkan analisis deskripsi terhadap skor yang diperoleh peserta didik setelah diterapkan pendekatan problem solving selama siklus I, maka diperoleh hasil yang terlihat pada tabel 1.

Tabel 1. Statistik Skor Hasil Belajar Peserta didik MTs Negeri 1 Makassar pada Siklus I

\begin{tabular}{cc}
\hline Statistik & Kualifikasi \\
\hline Subjek penelitian & 40 \\
Skor ideal & 100 \\
Skor tertinggi & 100 \\
Skor terendah & 48 \\
Rentang skor & 52 \\
Skor rata-rata & 79,48 \\
Standar deviasi & 12,88 \\
\hline
\end{tabular}

Berdasarkan tabel 1 tersebut, dapat diketahui bahwa skor rata-rata hasil belajar matematika peserta didik setelah diberikan tindakan adalah 79,48 dari skor ideal 100 . Skor tertinggi adalah 100 dan skor terendah adalah 48 dengan standar deviasi 12,88 dan dengan rentang skor 52. Apabila skor hasil belajar peserta didik pada siklus I dikelompokkan ke dalam 5 kategori, maka perolehan distribusi frekuensi skor yang ditunjukkan pada tabel 2.

Tabel 2. Distribusi Frekuensi dan Persentase Skor Siklus I MTs Negeri 1 Makassar

\begin{tabular}{ccccc}
\hline No & Interval & Kategori & Frekuensi & Persentase (\%) \\
\hline 1 & $0-34$ & Sangat rendah & 0 & $0 \%$ \\
2 & $35-54$ & Rendah & 2 & $5 \%$ \\
3 & $55-64$ & Sedang & 4 & $10 \%$ \\
4 & $65-84$ & Tinggi & 18 & $45 \%$ \\
5 & $85-100$ & Sangat tinggi & 16 & $40 \%$ \\
\hline \multicolumn{7}{r}{ Jumlah } & & 40 & 100 \\
\hline
\end{tabular}

Jika skor rata-rata hasil belajar peserta didik setelah pelaksanaan tindakan siklus I melalui pendekatan problem solving adalah 79,48 yang dikaitkan dengan tabel kategori tersebut, maka nilai rata-rata hasil belajar matematika berada pada kategori tingkat penguasaan tinggi. Apabila hasil belajar peserta didik pada siklus I dianalisis, maka persentase ketuntasan belajar peserta didik pada siklus I berdasarkan standar ketuntasan dapat dilihat pada tabel 3 . 
Tabel 3. Ketuntasan Belajar Peserta didik Kelas VIII9 MTs Negeri 1 Makassar pada Siklus I

\begin{tabular}{ccccc}
\hline No & Interval Skor & Kategori & Frekuensi & Persentase (\%) \\
\hline 1 & $0-79$ & Tidak tuntas & 14 & 35,00 \\
2 & $80-100$ & Tuntas & 26 & 65,00 \\
\hline \multicolumn{7}{r}{ Jumlah } & & 40 & 100 \\
\hline
\end{tabular}

Berdasarkan tabel 3 pada siklus I, persentase ketuntasan belajar sebesar 65,00\% yaitu 26 dari 40 peserta didik termasuk dalam kategori tuntas dan 35,00\% atau 14 dari 40 peserta didik termasuk dalam kategori tidak tuntas. Artinya tes siklus I bisa dikatakan baik, akan tetapi persentase ketuntasannya belum mencapai kriteria ketuntasan minimal yang telah ditetapkan yaitu $\geq 80 \%$. Peserta didik yang belum tuntas pembelajarannya perlu diberikan pengayaan berupa pembelajaran khusus secara individual yang dilakukan oleh guru di luar jam pembelajaran dan meminta kepada peserta didik yang telah mencapai ketuntasan belajar untuk membimbing temannya yang lain.

\section{Hasil Pengamatan Siklus II}

Berdasarkan analisis deskripsi terhadap skor yang diperoleh peserta didik setelah diterapkan pendekatan problem solving selama siklus II, maka diperoleh tabel 4 .

Tabel 4. Statistik Skor Hasil Belajar Peserta didik MTs Negeri 1 pada Siklus II

\begin{tabular}{cc}
\hline Statistik & Kualifikasi \\
\hline Subjek penelitian & 40 \\
Skor ideal & 100 \\
Skor tertinggi & 100 \\
Skor terendah & 60 \\
Rentang skor & 40 \\
Skor rata-rata & 89,40 \\
Standar deviasi & 9,68 \\
\hline
\end{tabular}

Berdasarkan tabel 4, dapat diketahui bahwa skor rata-rata hasil belajar matematika peserta didik setelah diberikan tindakan, yakni 89,40 dari skor ideal 100. Skor tertinggi adalah 100 dan skor terendah adalah 60 dengan standar deviasi 9,68 dan rentang skor 40. Apabila skor hasil belajar peserta didik pada siklus II dikelompokkan ke dalam 5 kategori, maka perolehan distribusi frekuensi skor yang ditunjukkan pada tabel 5.

Tabel 5. Distribusi Frekuensi dan Persentase Skor Siklus II MTs Negeri 1 Makassar

\begin{tabular}{ccccc}
\hline No & Interval & Kategori & Frekuensi & Persentase (\%) \\
\hline 1 & $0-34$ & Sangat rendah & 0 & $0 \%$ \\
2 & $35-54$ & Rendah & 0 & $0 \%$ \\
3 & $55-64$ & Sedang & 1 & $2,5 \%$ \\
4 & $65-84$ & Tinggi & 7 & $17,5 \%$ \\
5 & $85-100$ & Sangat tinggi & 32 & $80 \%$ \\
\hline \multicolumn{7}{r}{ Jumlah } & & 40 & 100 \\
\hline
\end{tabular}


Skor rata-rata hasil belajar peserta didik setelah pelaksanaan siklus II dengan menerapkan pendekatan problem solving dalam pembelajaran, diperoleh 89,40 dan jika dihubungkan dengan tabel kategori tersebut, maka nilai rata-rata hasil belajar matematika berada pada kategori tingkat penguasaan tinggi.

Apabila hasil belajar peserta didik pada siklus II dianalisis maka persentase ketuntasan belajar peserta didik pada siklus II yang berdasarkan standar ketuntasan yang diharapkan dapat dilihat pada tabel 6 .

Tabel 6. Ketuntasan Belajar Peserta didik Kelas VIII9 MTs Negeri 1 Makassar pada Siklus II

\begin{tabular}{ccccc}
\hline No & Interval Skor & Kategori & Frekuensi & Persentase (\%) \\
\hline 1 & $0-79$ & Tidak tuntas & 5 & 12,50 \\
2 & $80-100$ & Tuntas & 35 & 87,50 \\
\hline \multicolumn{7}{r}{ Jumlah } & & 40 & 100 \\
\hline
\end{tabular}

Berdasarkan tabel 6 pada siklus II, persentase ketuntasan belajar sebesar 87,50\% yaitu 35 dari 40 peserta didik berada pada kategori tuntas dan 12,50\% atau 5 dari 40 peserta didik berada pada kategori tidak tuntas. Artinya, dari tes siklus I hingga tes siklus II sudah mengalami peningkatan persentase ketuntasan klasikal, dan sudah berada di atas standar persentase ketuntasan klasikal. Hal ini disebabkan karena pada siklus II ini, para peserta didik sudah mulai memahami cara penyelesaian soal-soal yang diberikan oleh guru dengan menggunakan pendekatan pemecahan masalah. Selanjutnya, peningkatan hasil belajar matematika peserta didik setelah diterapkan pendekatan problem solving dalam proses belajar mengajar pada siklus I dan II, hasilnya dapat dilihat pada tabel 7.

Tabel 7. Distribusi Frekuensi dan Presentase Skor setelah Proses Pembelajaran pada Siklus I dan Siklus II.

\begin{tabular}{cclcccc}
\hline \multirow{2}{*}{ No. } & Skor(\%) & \multirow{2}{*}{ Kategori } & \multicolumn{2}{c}{ Frekuensi } & \multicolumn{2}{c}{ Persentase (\%) } \\
\cline { 4 - 7 } & & & Siklus I & Siklus II & Siklus I & Siklus II \\
\hline 1. & $0-34$ & Sangat rendah & 0 & 0 & 0 & 0 \\
2. & $35-54$ & Rendah & 2 & 0 & 5 & 0 \\
3. & $55-64$ & Sedang & 4 & 1 & 10 & 2,5 \\
4. & $65-84$ & Tinggi & 18 & 7 & 45 & 17,5 \\
5. & $85-100$ & Sangat tinggi & 16 & 32 & 40 & 80 \\
\hline
\end{tabular}

Pada tabel 7 terlihat adanya peningkatan hasil belajar matematika peserta didik kelas VII 9 MTs Negeri 1 Makassar dari setiap siklus dengan pendekatan pemecahan masalah (problem solving). Pada siklus I tingkat penguasaan materi berada pada kategori rendah, yaitu $2 \%$ dan pada siklus II jumlah peserta didik yang berada pada tingkat penguasaan materi rendah yaitu $0 \%$. Pada siklus I tingkat penguasaan materi adalah sedang, yaitu $10 \%$ dan pada siklus II jumlah peserta didik yang berada pada tingkat penguasaan materi sedang adalah 2,5\%. Pada siklus I tingkat penguasaan materi pada kategori tinggi, yaitu $45 \%$ dan pada siklus II jumlah peserta didik yang berada pada tingkat penguasaan materi tinggi yaitu $17,5 \%$, sedangkan pada kategori tingkat penguasaan materi sangat tinggi, pada siklus I hanya $40 \%$, namun pada siklus II terjadi peningkatan penguasaan materi sebesar $80 \%$. 
Jika skor rata-rata hasil belajar peserta didik setelah pelaksanaan tindakan siklus II melalui pendekatan problem solving adalah 89,40 yang dihubungkan dengan tabel kategori tersebut, maka nilai rata-rata hasil belajar matematika berada pada kategori tingkat penguasaan sangat tinggi.

\section{Refleksi siklus I}

Setiap pembelajaran yang dilaksanakan diawali dengan memberikan masalah dalam kehidupan sehari-hari yang berkaitan dengan materi pokok bahasan. Selanjutnya, peserta didik dikelompokkkan menjadi beberapa kelompok yang beranggotakan 4 atau 5 orang. Guru memandu peserta didik untuk menyelesaikan masalah tersebut dengan pendekatan problem solving. Dalam mengerjakan masalah tersebut, sebagian besar peserta didik belum mampu mengikuti langkah-langkah pemecahan masalah yang diberikan. Jika peserta didik kurang memahami masalah tersebut, peserta didik berusaha bertanya namun hanya satu sampai tiga orang saja yang bertanya, yang lain hanya melihat pekerjaan teman kelompoknya atau hanya mencatat tanpa mau berusaha untuk ikut aktif dalam menyelesaikan permasalahan yang diberikan. Ditemukan pula hanya peserta didik tertentu yang bersedia mempresentasikan hasil kerja kelompok mereka di papan tulis, sedangkan anggota yang lain hanya duduk diam di tempatnya, jadi guru lebih memotivasi peserta didik agar lebih aktif dalam bekerja sama.

Dalam proses belajar mengajar, pada umumnya peserta didik kurang memperhatikan arahan atau penjelasan dari guru, terlihat bahwa masih banyak peserta didik yang tidak mengerjakan tugas yang diberikan. Di samping itu, terdapat peserta didik yang minta izin keluar kelas dengan alasan ingin buang air kecil. Para peserta didik belum terbiasa dalam mengidentifikasi dan menyelesaikan masalah. Dalam memecahkan masalah yang sifatnya kompleks, sebagian besar peserta didik masih membutuhkan bimbingan, sehingga keterlibatan guru dalam membimbing dan mengarahkan peserta didik sangat diperlukan untuk meningkatkan keaktifan dan interaksi antara peserta didik serta memotivasi agar Bersama-sama dalam menyelesaikan masalah yang diberikan.

\section{Refleksi Siklus II}

Pelaksanaan pada siklus II pada dasarnya sama dengan siklus I, penekanan yang diberikan adalah bagaimana peserta didik mampu mengidentifikasi dan menyelesaikan masalah/soal-soal matematika. Pada siklus II ini, terlihat bahwa sebagian besar peserta didik telah dapat mengikuti langkah-langkah pendekatan pemecahan masalah (problem solving) yang digunakan dalam pembelajaran. Hal tersebut terlihat dari persentase jumlah peserta didik yang aktif dalam proses belajar mengajar mengalami peningkatan jika dibanding dengan siklus I yaitu banyaknya peserta didik yang berani mengajukan pertanyaan, termasuk juga hal-hal yang mereka kurang pahami dari masalah yang diberikan. Peserta didik juga sudah mulai terbiasa menyelesaiakan masalah sesuai langkahlangkah penyelesaian masalah dengan pendekatan problem solving, yaitu memahami masalah, merencanakan masalah, menyelesaikan masalah sesuai rencana, dan melakukan pengecekan kembali terhadap semua langkah yang dikerjakan. Setelah itu, guru memberikan bimbingan kepada peserta didik yang membutuhkan, serta meminta kepada setiap kelompok secara bergantian untuk mempersentasikan hasil kerjanya dan kelompok 
lain menanggapi. Jadi, hal tersebut membuat peserta didik termotivasi untuk menyelesaikan masalah yang diberikan.

Berdasarkan hasil analisis yang dilakukan penulis, menunjukkan bahwa jumlah peserta didik yang bertanya atau memberikan tanggapan terhadap masalah yang diberikan terus mengalami peningkatan. Pada siklus I, masalah-masalah yang mampu dipecahkan peserta didik masih berupa masalah yang masih sederhana. Namun, pada masalah yang lebih kompleks, peserta didik masih membutuhkan bimbingan guru/peneliti untuk memahami dan menyelesaikannya. Hal ini disebabkan karena peserta didik belum terbiasa menyelesaikan soal-soal pemecahan masalah. Pada siklus II, sebagian besar peserta didik telah dapat memahami dan menyelesaikan soal-soal pemecahan masalah dengan baik. Jadi, terlihat bahwa secara kuantitatif hasil belajar matematika peserta didik kelas VII9 MTs Negeri 1 Makassar mengalami peningkatan. Oleh karena itu, melalui pendekatan problem solving, peserta didik mendapatkan pengalaman ketika diberikan soal-soal terkait pemecahan masalah. Penelitian ini pertama kali dilakukan di kelas VII. MTs Negeri 1 Makassar dengan menyajikan masalah-masalah matematika melalui penerapan pendekatan problem solving dengan tujuan untuk meningkatkan hasil belajar matematika peserta didik. Penelitian ini diperkuat oleh penelitian yang dilakukan oleh Surya (2017) bahwa penerapan pendekatan problem solving dapat meningkatkan hasil belajar IPA peserta didik di Kelas IV SD. Selain itu penelitian yang dilakukan oleh Gustrianingsih (2013) menemukan bahwa melalui penerapan pendekatan problem solving dapat meningkatkan motivasi dan hasil belajar matematika peserta didik di Kelas VII A SMP Taman Dewasa Ibu Pawiyatan Yogyakarta. Demikian juga penelitian yang dilakukan oleh Aedi (2020), menemukan bahwa hasil belajar matematika dapat meningkat melalui pendekatan pemecahan masalah. Secara umum dapat dikatakan bahwa proses belajar mengajar pada siklus II ini mengalami peningkatan dibandingkan dengan siklus I. Setelah diberikan tes akhir siklus II, diperoleh bahwa skor rata-rata peserta didik dalam menyelesaikan masalah/soal mengalami peningkatan dari siklus I. Dengan demikian, prestasi peserta didik lebih meningkat.

\section{SIMPULAN}

Penerapan pendekatan problem solving dalam pembelajaran matematika dapat meningkatkan hasil belajar matematika peserta didik kelas VII. MTs Negeri 1 Makassar, terlihat bahwa skor rata-rata hasil belajar matematika peserta didik pada siklus I sebesar 79,48\% meningkat pada siklus II menjadi 89,40\%. Pada siklus I, persentase peserta didik yang memenuhi KKM adalah $65 \%$, dan pada siklus II meningkat menjadi 87,50 \%. Oleh karena itu, dapat dikatakan bahwa hasil belajar matematika peserta didik dapat meningkat melalui penerapan pendekatan problem solving. Dengan demikian, prestasi peserta didik lebih meningkat.

\section{DAFTAR PUSTAKA}

Aedi. W. G. (2020). Upaya meningkatkan hasil belajar matematika dengan pendekatan problem solving. JIPMat (Jurnal Ilmiah Pendidikan Matematika). 5(1). DOI: $10.26877 /$ jipmat.v5i1.5889.

Alipandie, I. (1984). Didaktik metodik pendidikan umum. Surabaya: Usaha Nasional. 
Aris, S. (2014). Model pembelajaran inovatif dalam kurikulum 2013. Yogyakarta: AR-ruz Media.

Gustrianingsih. (2013). Upaya meningkatkan motivasi dan hasil belajar matematika dengan pendekatan problem solving siswa SMP kelas VII A Taman Dewasa Ibu Pawiyatan Yogyakarta Tahun Ajaran 2012/2013. UNION: Jurnal Pendidikan Matematika, 1(1), 17-24. DOI: http://dx.doi.org/10.30738/.v1i1.4.

Hamalik, O. (2003). Kurikulum dan pembelajaran cetakan keempat. Jakarta: Bumi Aksara.

Harahap, H. H., \& Makmur, A. (2018). Penerapan model pembelajaran Numbered Heads Together (NHT) untuk meningkatkan pemahaman konsep matematika peserta didik SMP Negeri 4 Padangsidimpuan. Nabla Dewantara: Jurnal Pendidikan Matematika, 3(2), 40-49. Retrieved from http://www.ejournal.unitaspalembang.ac.id/index.php/nabla/article/view/90.

Hidayat, W. \& Sariningsih. (2018). Kemampuan pemecahan masalah matematis dan adversity quotient siswa SMP melalui pembelajaran open ended. JNPM (Jurnal $\begin{array}{llll}\text { Nasional Pendidikan } & \text { Matematika), }\end{array}$ DOI: http://dx.doi.org/10.33603/jnpm.v2i1.1027.

Imelda. (2018). Penerapan metode problem solving dalam meningkatkan kemampuan pemecahan masalah pada mata kuliah aljabar dan trigonometri. MES Journal of Mathematics Education and Science), 3(2). DOI: https://doi.org/10.30743/mes.v3i2.496.

Lubis, M. A., \& Azizan, N. (2018). Penerapan model pembelajaran problem based learning untuk meningkatkan hasil belajar matematika di SMP Muhammadiyah 07 Medan Perjuangan Tahun Pelajaran 2018/2019. Logaritma, 6(2), 150-163. DOI: https://doi.org/10.24952/logaritma.v6i02.1282.

Kusumaningtyas, W. (2016). Efektivitas metode inquiry terhadap hasil belajar matematika peserta didik. Jurnal E-DuMath, 2(1), 102-108. DOI: https://doi.org/10.26638/je.163.2064.

Maesari, C., Marta, R., \& Yusnira. (2020). Penerapan model pembelajaran problem solving untuk meningkatkan kemampuan pemecahan masalah matematika peserta didik sekolah dasar. Jurnal Pendidikan dan Konseling, 1(2), 92-102. https://journal.universitaspahlawan.ac.id/index.php/jote/article/view/508.

Mardianis (2018). Upaya meningkatkan hasil belajar siswa dengan penerapan metode pembelajaran problem solving terhadap pembelajaran IPA siswa kelas VI SD Negeri 020 Tembilahan Hilir. Jurnal PAJAR (Pendidikan dan Pengajaran), 1(1), 11-18. DOI: $10.33578 /$ pjr.v2i1.4871.

Mustami, M. K. (2012). Dimensi-dimensi Penelitian Tindakan Kelas (Cet. I). Makassar: UIN Alauddin Press.

Nengsih, L. W., Susiswo, Sa'dijah, C. (2019). Kemampuan pemecahan masalah matematika peserta didik sekolah dasar dengan gaya kognitif field dependent. Jurnal Pendidikan: Teori, Penelitian, dan Pengembangan, 4(2), 143-148. DOI: http://dx.doi.org/10.17977/jptpp.v4i2.11927.

Nur'aini, I. L., Harahap, E., Badruzzaman, F. H., \& Darmawan, D. (2017). Pembelajaran matematika geometri secara realistis dengan GeoGebra. Jurnal Teori Dan Terapan Matematika, 16(2), 1-6. DOI: https://doi.org/10.29313/jmtm.v16i2.3900.

Surya, Y. F. (2017). Penerapan pendekatan problem solving untuk meningkatkan hasil belajar siswa pada pembelajaran IPA Kelas IV SD. JS (Jurnal Sekolah), 1 (2). DOI: https://doi.org/10.24114/js.v1i2.7315. 